\title{
Contents of Volume 120 (2005)
}

\author{
Authors and Titles \\ 1509 (Oct.) BADOWSKA, EVA (Fordham Univ., Rose Hill). Choseville: Brontë's Villette \\ and the Art of Bourgeois Interiority \\ 341 (Mar.) BERGER, JAMES (Hofstra Univ.). Falling Towers and Postmodern Wild \\ Children: Oliver Sacks, Don DeLillo, and Turns against Language \\ 734 (May) BROWN, BILL (Univ. of Chicago). The Dark Wood of Postmodernity (Space, \\ Faith, Allegory) \\ 362 (Mar.) BUCKWALTER-ARIAS, JAMES (Hanover Coll.). Reinscribing the Aes- \\ thetic: Cuban Narrative and Post-Soviet Cultural Politics \\ 822 (May) BUTLER, JUDITH (Univ. of California, Berkeley). Photography, War, Out- \\ rage (Theories and Methodologies) \\ 33 (Jan.) CAMPANA, JOSEPH (Kenyon Coll.). On Not Defending Poetry: Spenser, \\ Suffering, and the Energy of Affect \\ 1576 (Oct.) CHRISTIE, STUART (Hong Kong Baptist Univ.). Disorientations: Canon \\ without Context in Auden's "Sonnets from China" \\ 181 (Jan.) CLUNE, MICHAEL (Johns Hopkins Univ.). "Everything We Want": Frank \\ O'Hara and the Aesthetics of Free Choice \\ 806 (May) EBURNE, JONATHAN P. (Pennsylvania State Univ., University Park). The \\ Transatlantic Mysteries of Paris: Chester Himes, Surrealism, and the Sé- \\ rie noire \\ 843 (May) EDWARDS, AMELIA BLANDFORD. The Social and Political Position of \\ Woman in Ancient Egypt (1887). Introduction by Patricia O'Neill (Hamil- \\ ton Coll. [Little-Known Documents]) \\ 375 (Mar.) FRANCO, DEAN (Wake Forest Univ.). Working Through the Archive: \\ Trauma and History in Alejandro Morales's The Rag Doll Plagues \\ 1524 (Oct.) GOEHRING, EDMUND J. (Univ. of Western Ontario). The Lamentations of \\ Don Juan and Macbeth \\ 1608 (Oct.) GOLDBERG, JONATHAN (Johns Hopkins Univ.), and MADHAVI MENON \\ (American Univ.). Queering History (The Changing Profession) \\ 388 (Mar.) GOTTLIEB, SUSANNAH YOUNG-AH (Northwestern Univ.). Two Versions \\ of Voltaire: W. H. Auden and the Dialectic of Enlightenment \\ 219 (Jan.) GREENE, VIRGINIE (Harvard Univ.). Three Approaches to Poetry \\ 66 (Jan.) HAYOT, ERIC R. J. (Univ. of Arizona). The Strange Case of Araki Yasusada: \\ Author, Object \\ 1618 (Oct.) HUHNDORF, SHARI (Univ. of Oregon). Literature and the Politics of Na- \\ tive American Studies (The Changing Profession) \\ 858 (May) JELINEK, ELFRIEDE. Sidelined / Im Abseits (Nobel Lecture 2004)
}

(C) 2005 BY THE MODERN LANGUAGE ASSOCIATION OF AMERICA 
KIRSHENBLATT-GIMBLETT, BARBARA (New York Univ.). See Editor's Column (Oct.), under "Miscellaneous."

1560 (Oct.) KOLB, KATHERINE (Southeastern Louisiana Univ.). The Tenor of "Sarrasine"

1543 (Oct.) KRIMMER, ELISABETH (Univ. of California, Davis). "Eviva il Coltello"? The Castrato Singer in Eighteenth-Century German Literature and Culture

1628 (Oct.) LADD, BARBARA (Emory Univ.). Literary Studies: The Southern United States, 2005 (The Changing Profession)

1588 (Oct.) LYND, JULIET (Saint Olaf Coll.). Precarious Resistance: Weaving Opposition in the Poetry of Cecilia Vicuña

796 (May) MARTÍN-RODRÍGUEZ, MANUEL M. (Univ. of California, Merced). Recovering Chicano/a Literary Histories: Historiography beyond Borders

163 (Jan.) McDIARMID, LUCY (Villanova Univ.). A Box for Wilfrid Blunt MENON, MADHAVI. See GOLDBERG, JONATHAN, and MADHAVI MENON

828 (May) MILLER, NANCY K. (Graduate Center, City University of New York). Regarding Susan Sontag (Theories and Methodologies)

327 (Mar.) MOHAMED, FEISAL G. (Texas Tech Univ.). Confronting Religious Violence: Milton's Samson Agonistes

715 (May) MORRISON, TONI (Princeton Univ.), GAYATRI CHAKRAVORTY SPIVAK (Columbia Univ.), and NGAHUIA TE AWEKOTUKU (Univ. of Waikato). Guest Column: Roundtable on the Future of the Humanities in a Fragmented World

422 (Mar.) NICHOLS, STEPHEN G. (Johns Hopkins Univ.). Writing the New Middle Ages (The Changing Profession)

108 (Jan.) NOLAND, CARRIE. Phonic Matters: French Sound Poetry, Julia Kristeva, and Bernard Heidsieck

O'NEILL, PATRICIA. See EDWARDS, AMELIA BLANDFORD.

442 (Mar.) PETERS, JULIE STONE (Columbia Univ.). Law, Literature, and the Vanishing Real: On the Future of an Interdisciplinary Illusion (The Changing Profession)

97 (Jan.) Poetry and Theory: A Roundtable

454 (Mar.) ROBBINS, BRUCE (Columbia Univ.). Commodity Histories (The Changing Profession)

148 (Jan.) ROBSON, CATHERINE (Univ. of California, Davis). Standing on the Burning Deck: Poetry, Performance, History

16 (Jan.) RONELL, AVITAL (New York Univ.). On the Misery of Theory without Poetry: Heidegger's Reading of Hölderlin's "Andenken"

834 (May) SAYRES, SOHNYA (Cooper Union). For Susan Sontag, 1933-2004 (Theories and Methodologies)

724 (May) SCHOLES, ROBERT (Brown Univ.). Presidential Address 2004: The Humanities in a Posthumanist World

9 (Jan.) SMITH, BRUCE R. (Univ. of Southern California). Introduction: Some Pre $_{\text {sup }}$ positions

49 (Jan.) SPARGO, R. CLIFTON (Marquette Univ.). The Ethical Uselessness of Grief: Randall Jarrell's "The Refugees"

SPIVAK, GAYATRI CHAKRAVORTY. See MORRISON, TONI, GAYATRI CHAKRAVORTY SPIVAK, and NGAHUIA TE AWEKOTUKU.

235 (Jan.) STEWART, SUSAN (Princeton Univ.). What Praise Poems Are For

839 (May) SULEIMAN, SUSAN RUBIN (Harvard Univ.). Culture, Aestheticism, and Ethics: Sontag and the "Idea of Europe" (Theories and Methodologies)

768 (May) SURWILLO, LISA (Pennsylvania State Univ., University Park). Representing the Slave Trader: Haley and the Slave Ship; or, Spain's Uncle Tom's Cabin

TAYLOR, DIANA (New York Univ.). See Editor's Column (Oct.), under "Miscellaneous."

TE AWEKOTUKU, NGAHUIA. See MORRISON, TONI, GAYATRI CHAKRAVORTY SPIVAK, and NGAHUIA TE AWEKOTUKU.

82 (Jan.) TIFFANY, DANIEL (Univ. of Southern California). Fugitive Lyric: The Rhymes of the Canting Crew

197 (Jan.) WALKER, ERIC C. (Florida State Univ.). The Muse of Indifference

128 (Jan.) WALL-ROMANA, CHRISTOPHE (Univ. of California, Berkeley). Mallarmé's Cinepoetics: The Poem Uncoiled by the Cinématographe, 1893-98

404 (Mar.) WEBER, ALISON (Univ. of Virginia). Lope de Vega's Rimas sacras: Conversion, Clientage, and the Performance of Masculinity

751 (May) WHITE, ED (Louisiana State Univ., Baton Rouge). Invisible Tagkanysough 

cultural Reading

\section{Conference on Disability Studies and the University (Mar.)}

BAYNTON, DOUGLAS (Univ. of Iowa). Slaves, Immigrants, and Suffragists: The Uses of Disability in Citizenship Debates

BÉRUBÉ, MICHAEL (Pennsylvania State Univ., University Park). Disability and Narrative

BRUEGGEMANN, BRENDA JO (Ohio State Univ., Columbus). Deaf, She Wrote: Mapping Deaf Women's Autobiography

COUSER, G. THOMAS (Hofstra Univ.). Disability, Life Narrative, and Representation

DAVIDSON, MICHAEL (Univ. of California, San Diego). Concerto for the Left Hand: Disability (in the) Arts

DAVIDSON, MICHAEL (Univ. of California, San Diego), and TOBIN SIEBERS (Univ. of Michigan, Ann Arbor). Introduction

DAVIS, LENNARD J. (Univ. of Illinois, Chicago). Disability: The Next Wave or Twilight of the Gods?

EIESLAND, NANCY (Emory Univ.). Encountering the Disabled God

FEAL, ROSEMARY G. (MLA). Acknowledgments

FINGER, ANNE (Oakland, CA). Writing Disabled Lives: Beyond the Singular

GARLAND-THOMSON, ROSEMARIE (Emory Univ.). Disability and Representation

GILMAN, SANDER L. (Emory Univ.). Defining Disability: The Case of Obesity

JORDAN, I. KING (Gallaudet Univ.). The Gallaudet Experience: Deafness and Disability

KLEEGE, GEORGINA (Univ. of California, Berkeley). Reflections on Writing and Teaching Disability Autobiography

KRENTZ, CHRISTOPHER (Univ. of Virginia). A "Vacant Receptacle"? Blind Tom, Cognitive Difference, and Pedagogy

KUDLICK, CATHERINE J. (Univ. of California, Davis). Disability History, Power, and Rethinking the Idea of "the Other"

LACOM, CINDY (Slippery Rock Univ.). "The Time Is Sick and Out of Joint": Physical Disability in Victorian England

LINTON, SIMI (New York, NY). What Is Disability Studies?

LONGMORE, PAUL K. (San Francisco State Univ.). The Cultural Framing of Disability: Telethons as a Case Study

McRUER, ROBERT (George Washington Univ.). Crip Eye for the Normate Guy: Queer Theory and the Disciplining of Disability Studies

MILLER, PAUL STEVEN (Univ. of Washington, Seattle). Developing Diversity and Equal Opportunity: Why the Disability Perspective Matters

MITCHELL, DAVID T. (Univ. of Illinois, Chicago), and SHARON L. SNYDER (Univ. of Illinois, Chicago). Compulsory Feral-ization: Institutionalizing Disability Studies

NEWBY, WENDY L. (Emory Univ.). Voices from the Classroom

PADDEN, CAROL A. (Univ. of California, San Diego). Talking Culture: Deaf People and Disability Studies

PRICE HERNDL, DIANE (Iowa State Univ.). Disease versus Disability: The Medical Humanities and Disability Studies

SANDAHL, CARRIE (Florida State Univ.). From the Streets to the Stage: Disability and the Performing Arts

SHEPPARD, ALICE (Pennsylvania State Univ., University Park). After Words SIEBERS, TOBIN (Univ. of Michigan, Ann Arbor). Disability Aesthetics. See also DAVIDSON, MICHAEL, and TOBIN SIEBERS.

SNYDER, SHARON L. (Univ. of Illinois, Chicago). Geographies of Uneven Development: How Does One Make Disability Integral to Higher Education? See also MITCHELL, DAVID T., and SHARON L. SNYDER. 


\section{Miscellaneous}

1036 (Dir) Association Statistics

987 (Dir.) Committees and Commissions

1382 (Dir.) Comparative Literature Departments and Programs

1040 (Dir.) A Concise Guide to Activities and Services

1014 (Dir.) Constitution

1002 (Dir.) Contributors to the 2004 MLA International Bibliography

1022 (Dir.) Delegate Assembly Bylaws

Departmental Administrators

1331 (Dir.) Four-Year Colleges and Universities

1354 (Dir.) Two-Year Colleges

1468 (Dir.) Directory of Useful Addresses

1036 (Dir.) Distribution of Members

994 (Dir.) Divisions and Discussion Groups

321 (Mar.) Editor's Column

713 (May) Editor's Note

1497 (Oct.) Editor's Column

1369 (Dir.) Ethnic Studies Programs

1038 (Dir.) Executive Directors

1386 (Dir.) Fellowships and Grants

246 (Jan.) Forum

464 (Mar.) Forum: The Legacy of Jacques Derrida

874 (May) Forum: Responses to Bill Brown's “The Dark Wood of Postmodernity (Space,

886 (May) Forum

1640 (Oct.) Forum

983 (Dir.) Governance Structure: Officers, Executive Council, Delegate Assembly

1052 (Dir.) Honorary Fellows

1051 (Dir.) Honorary Members

1384 (Dir.) Humanities Research Centers

1329 (Dir.) In Memoriam

1372 (Dir.) Language and Area Programs

1053 (Dir.) Members

1038 (Dir.) Members of the Executive Council, 1991-2005

1049 (Dir.) The MLA Staff

1037 (Dir.) The One Hundred Fifteen Presidents

1384 (Dir.) Organizations for Independent Scholars

1038 (Dir.) PMLA Editors

1009 (Dir.) Policies for Divisions, Discussion Groups, and Allied and Affiliate Organizations

1026 (Dir.) Prizes

1003 (Dir.) Procedures for Organizing Meetings at the MLA Convention

268 (Jan.) Professional Notes and Comment

658 (Mar.) Professional Notes and Comment

924 (May) Professional Notes and Comment

1662 (Oct.) Professional Notes and Comment

892 (May) Report of the Executive Director

1375 (Dir.) Women's Studies Programs 